\title{
DIE BEHOEFTE VAN DIE GEHOSPITALISEERDE KLEUTER IN OPVOEDINGSPERSPEKTIEF
}

ANNALI BASSON

\section{INLEIDING}

We have to be aware all the time that we are not just looking after a baby. We are educating a human being . . . (Wright, 1972:10).

Bogenoemde stelling impliseer dat enige persoon wat die verantwoordelikheid aanvaar om 'n voorskoolse kind, siek of gesond, te versorg noodwendig aanspreeklik is vir daardie kind se behoeftes in totaliteit. Hierdie behoeftes sluit ook opvoeding in, aangesien die kind op opvoeding aangewese is veral gedurende die voorskoolse jare.

Die hospitalisering van 'n kind impliseer noodwendig verandering in sy totale lewenspatroon. Hy word uit ' $n$ bekende en veilige omgewing geneem na 'n onbekende situasie. Die verdere feit dat hy siek is, vererger hierdie verandering en bemoeilik die aanpassing sodat daar dikwels onnodige angs ontstaan (Piek, $1981:$ 1).

Opvoeding is primêr die taak en die verantwoordelikheid van die ouers (Muller, 1979: 1). As die kind gehospitaliseer word, wil dit voorkom of hierdie verantwoordelikheid ook deel word van die verpleegpersoneel se funksie in die kind se daaglikse versorging.

Navorsing gedoen deur van Rensburg (1981 : 26) het aangetoon dat:

- op enige tydstip, 20 tot 30 persent van alle kinders in ' $n$ hospitaal in werklikheid onnodig gehospitaliseer is

- elke kind in 'n hospitaal, afhangende of dit 'n klein hospitaal of 'n groot opleıdıngshospitaal is, daagliks blootgestel word aan tien tot dertig vreemde mense

Dr A. Basson, B.Cur (Ed et Admin) (RAU); M Cur (RAU); D. Verpleegkunde (US); AV; VV, PV, GGV, VO, VA.

Senior Lektrise, Departement Verpleegkunde, RAU.

\section{SUMMARY}

When nursing a pre-school child, meeting his total needs includes giving attention to the child's developmental (educational) needs.

Criteria against which nurses' supportive interaction with hospitalised toddlers could be evaluated were designed. It was found that nurses in paediatric wards give very little attention to their patients' developmental needs. However, after an inservice education programme designed for this purpose a marked improvement in the nurses' interaction was measured.

It is recommended that nurses coming into paediatric wards need a special orientation programme and that inservice education and learning opportunities should be offered to staff on a continuous basis. This would equip them with the required knowledge and skills to meet the total needs of their patients.

- meer as 60 persent van die geneeshere nie op die hoogte is met die administrasie van die hospitaal of die werkswyse en organisasie van die saal waarin die kind opgeneem word nie.

Volgens laasgenoemde aspek wil dit voorkom of so 'n geneesheer nie 'n bydrae daartoe kan lewer om die kind en sy ouers voor te berei en in te lig oor wat hospitalisering moontlik vir die kind kan inhou nie.

In die hospitaal is alles op die sieke ingestel — die pasiënt word dus meer afhanklik en soek dikwels in die verpleegkundige se versorging sy enigste beskerming teen die saaklike atmosfeer van die hospitaal (Elliot, 1975: 33).

Die verpleegkundige, op haar beurt, moet haar funksie uitleef en die kind as totale mens verpleeg en volgens Yura en Walsh $(1973: 11)$ het hierdie kind geestelike, psigiese en fisieke gesondheidsbehoeftes.

Die vraag word gestel of die huidige toepassing van die proses van verpleging voldoen aan die eise wat kinderhospitalisering meebring en of die kind se opvoedingsbehoeftes die nodige aandag kry?

\section{LITERATUURSTUDIE Die Kleuter}

Die kind van ongeveer twee tot ses jaar oud staan in die literatuur dikwels bekend as die kleuter (Engelbrecht, Kok en van Biljon, 1982 : 51).
Hierdie tydperk van 'n kind se lewe word normaalweg daardeur gekeńmerk dat sy denke en gevoelens dadelik in woorde en handelinge uitdrukking vind (Erikson, 1975 : 8). So 'n kind se gedrag is reeds makliker vertolkbaar as die van die jonger kind en dit is nog nie so ingewikkeld soos dié van die ouer kind nie.

Garbers (1981 : 3) wys egter daarop dat hoewel daar reeds maklik met die kleuter gekommunikeer kan word, hy nog boeiende, tipies kinderlike foutiewe vertolkings en vergissings manifesteer.

Die vyfjarige kind bevind hom in 'n periode van relatief gelykmatige ontwikkeling waarin sy rustigheid en rypheid hom duidelik van jonger kinders onderskei (Bigot, 1968 : 63). Hy is nog baie afhanklik van die geborgenheid van die gesinsmilieu en die goedkeuring van volwassenes. Sy konsentrasie is dan ook die grootste wanneer sy ouers in die onmiddellike nabyheid is en 'n veilige en rustige atmosfeer skep. Die behoefte aan veiligheid en rustigheid kom tot uiting in 'n verlange na 'n vaste daaglikse roetine en die aandrang op die presiese herhaling van rympies en verhale (Garbers, 1981:7) 


\section{Liggaamlike ontwikkeling}

Die ontwikkelingstake van die kleuter hang ten nouste saam met die oorkoepelende taak om in liggaamlike, motoriese, emosionele, kognitiewe en sosiale opsig te vorder tot op 'n vlak wat hom in staat stel om die skool met welslae by te woon (Bower, 1979 : 277).

Craig (1983 : 315) konstateer dat dit baie moeilik is om gedurende die kleuterjare liggaamlik-motoriese en perseptuele ontwikkeling van kognitiewe ontwikkeling te skei. Die kleuter se begrip van die wêreld is immers afhanklik van die inligting wat hy ontvang van sy eie liggaam, waarnemings, motoriese aktiwiteite en die wyse waarop hy homself ervaar.

Deur te kyk, te voel en te praat, probeer die kind sy ingewikkelde ontwikkelingstake bemeester. Volgens Kolesnik (1978 : 81) moet die opvoeder die kind motiveer deur hom voortdurend aan te moedig en aan te prys as hy hierdie take met welslae uitvoer.

Die stel van realistiese verwagtinge van die kind is volgens Smith (1983 : 11) 'n belangrike motiveringsfaktor. Hierdie stelling word deur navorsers soos Atkinson (1968 : 54) en Rethlingshafer (1963: 144) onderskryf. Wanneer verwagtinge en eise te hoog is, kan dit lei tot frustrasie en verlies aan motivering, terwyl té lae verwagtinge 'n onvoldoende uitdaging vir die kind kan inhou.

\section{Kognitiewe ontwikkeling}

Psigiese ontwikkeling in die kleuterjare word veral gekenmerk deur die vinnige toename in kognitiewe vermoëns (Vander Zanden, 1981 : 109). Die kind se totale kognitiewe ontwikkeling is afhanklik van die doeltreffende rypwording van sy perseptuele sisteme. Hierdie sisteme is weer afhanklik van die skerpheid van die kind se sensoriese sintuie.

Waar die sensories-motoriese prosesse gedurende die babajare oorheersend was, vind daar nou 'n betekenisvolle oorgang na die meer abstrakte prosesse van redenering, afleiding en probleemoplossing plaas (Lerner \& Hultsch, 1983 : 273).
Hoewel die kind se taalontwikkeling reeds voor sy tweede verjaardag begin, is sy eerste taalgebruik in 'n hoë mate egosentries (Ginsberg \& Opper, 1979 : 23). Om gesosialiseerde taal wat vir duidelike kommunikasie geskik is aan te leer, is dit nodig dat die kind deur die opvoeders gestimuleer word (Piaget \& Inhelder, $1969: 56$ ).

\section{Persoonlikheidsontwikkeling}

Hoewel babas reeds van geboorte af van mekaar verskil, tree individuele verskille in die kleuterjare baie sterk na vore (Craig, 1983 : 117). Dit lyk of daar meer reëlmaat en patroon in sy gedrag is. Volgens Bower (1979 : 79) word dit in 'n groot mate teweeggebring deur die kleuter se duideliker omlyning van sy selfkonsep en sy identifisering met die geslagsrol. Vervolgens word kortliks gekyk na hierdie twee fasette van persoonlikheidsontwikkeling.

\section{Die ontwikkeling van die selfkonsep}

Die selfkonsep is die persoon se siening of beeld van homself. Die selfkonsep sluit sake soos 'n selfbeeld, selfagting en selfaanvaarding in (Allport, 1979 : 33).

Die kleuter se selfbeeld is dus sy innerlike beeld of siening van homself. Sienings soos $e k$ is 'n seun met bruin oë en swart hare wat kan driewiel ry is 'n voorbeeld van wat 'n kind van homself dink.

Allport (1979: 82) is voorts van mening dat selfagting 'n persoonlike evaluasie van jou eienskappe is. Die kleuter leer grootliks deur andere se evaluering van homself of hy slim, suksesvol of mooi is. Uit hierdie evaluering van ander ontwikkel die kleuter se selfagting.

'n Persoon se selfkonsep is positief in soverre hy sy eienskappe as goed en aanvaarbaar evalueer en negatief is soverre hy met sy eienskappe ontevrede is (Erikson, 1968: 51).

Selfagting en selfbeeld hang dus ten nouste saam en die mate van selfaanvaarding speel 'n belangrike rol in die kind se persoonlikheidsontwikkeling en beïnvloed alle aspekte van sy funksionering. Kinders met 'n negatiewe selfkonsep het gewoonlik 'n hoë angsvlak
(Bledsoe, 1964: 48) en toon ook later swak skoolvordering en sosiale aanpassing (Sears, 1970 : 89). Laasgenoemde ondersoeker meen ook dat kinders met 'n positiewe selfkonsep akademies beter presteer en sosiaal makliker inskakel. Hulle het baie selfvertroue en is nie skaam om menings uit te spreek nie.

\section{Die ontwikkeling van geslagsrolidentiteit}

'n Besonder belangrike aspek van die individu se selfkonsep in sy siening van homself as ' $n$ lid van of die manlike of die vroulike geslag en die aanvaarding van die daarmee gepaardgaande kultureel aanvaarde gedragswyses. Volgens Vander Zanden (1981: 321) begin die proses reeds kort ná geboorte en die ontwikkeling in die kleuterjare speel 'n besonder belangrike rol.

Kohlberg (1966: 174) wys daarop dat die kind se definiëring van homself as manlik of vroulik in stappe geskied. So kan driejarige kinders hulself dikwels reeds as seun of meisie identifiseer en hulle weet dat vroue rokke dra en dat mans skeer en vroue nie. Die besef dat hulle onveranderlik en permanent lid van 'n spesifieke geslag is, word egter eers later duidelik. Navorsing van Bhana (1983 : 12) onder Indiërkinders in Suid-Afrika skyn Kohlberg se vertolking te bevestig.

\section{Sosialisering en sosiale ontwikkeling}

Hoewel die aard van sosialisering van individu tot individu en van kultuur tot kultuur kan verskil, lyk dit of baie psigoloë meen dat dieselfde individuele en sosiale meganismes by alle kinders in alle kulture aanwesig is (Schell \& Hall, $1979: 216$ ). Fein (1978: 128) beskryf vier basiese meganismes soos volg:

- die begeerte om affeksie, agting, aanvaarding en erkenning te verkry

- die wens om die onaangename gevoelens wat op verwerping of straf volg te vermy

- die neiging om die optrede van ander na te boots

- Die begeerte om te wees soos spesifieke mense wat die kind geleer het om te respekteer, te bewonder of lief te hê - 'n proses bekend as identifikasie. 
Erikson (1968 : 214) onderskei tussen eksterne en interne faktore in die sosialiseringsproses.

\section{Eksterne faktore}

Deur die sosialiseringsproses word morele waardes, tradisies en gedragsnorme aan die kind oorgedra en wel deur ' $n$ verskeidenheid van bedrywighede soos spel, nabootsing en verbale interaksie tussen die kind en die sosialiseringsagent.

\section{Interne faktore}

Temperament is onder meer een van die interne faktore wat sal bepaal hoe die kind op sosialiseringsaksies deur andere sal reageer. Buss en Plomin (1975 : 44) meen dat vier temperamentseienskappe, naamlik emosionaliteit, aktiwiteit, impulsiwiteit en geselligheid geneties bepaal word en lê oortuigende bewyse van 'n genetiese oorsprong voor.

Thomas en Chess (1977 : 222) meen egter dat geslag en intellektuele vermoëns ook die sosialiseringsproses beïnvloed. Die dogter word in sekere opsigte anders gesosialiseer as die seun. Daar word byvoorbeeld verwag dat sy eerder met 'n pop as met 'n geweer sal speel. Voorts sal intellektuele vermoëns onder meer bepaal hoe vinnig sekere vaardighede aangeleer kan word.

\section{Emosionele Ontwikkeling}

Wat die emosionele ontwikkeling van die kleuter betref word kortliks aandag geskenk aan vrees, gehegtheid en emosionele geluk.

\section{Vrees}

Vrees is in mindere of meerdere mate by alle mense van alle ouderdomsgroepe aanwesig. Dit is deel van menswees en inderdaad ook soms nodig om selfbeskermingsaksies te aktiveer (Hall, Lamb \& Perlmuther, $1982: 271$ ).

Daar is deur Sarafina en Armstrong (1980:284) gevind dat kinders tussen twee- en vyfjarige ouderdom se vrese vir dinge soos honde, geraas, pyn, skielike bewegings en vreemde voorwerpe afneem. In dieselfde stadium is daar egter 'n toename in vrese vir die donker, skeppings van die verbeelding en dinge wat bedreigend is, soos vuur of diep water.

\section{Gehegtheid}

Kinders van twee- en driejarige ouderdom is nog geneig om sterk gehegtheid aan ouers te toon. Hierdie gehegtheid neem egter geleidelik ander vorms aan, soos daaruit blyk dat kinders toenemend minder gereeld na hul ouers terugbeweeg en minder aan hulle vasklou (Bee, 1981 : 297).

Ondanks die kind se toenemende onafhanklikheid van veral sy moeder, sal die kleuter met skeiding nogtans baie vrees ervaar veral as hierdie skeiding gekoppel word aan 'n vreemde omgewing (Sarafina \& Armstrong, 1980 : 291).

Piek (1981 : 14) meen dat dit nog erger is wanneer die vreemde omgewing met pyn en onaangenaamheid geassosieer word, soos byvoorbeeld hospitalisering van die kind.

\section{Emosionele geluk}

Oor die algemeen kan die kleutertydperk 'n emosioneel gelukkige tydperk wees. Dit is 'n tydperk van ontdekking en toenemende bekwaamheid, 'n tydperk van aksie (Bigner, 1983 : 89). Hurlock (1980 : 247) noem die volgende faktore wat tot die kleuter se geluk bydra:

- 'n stimulerende omgewing

- aanvaarding deur die opvoeder van irriterende gedrag van die kind

- 'n beleid van dissipline wat konsekwent toegepas word sodat kinders weet wat van hulle verwag word.

- ontwikkelings-toepaslike uitdrukking van die ouers se geneentheid, soos trots op die kind se prestasie

- realistiese strewe wat ooreenstem met die kind se vermoëns

- aanmoediging van skeppende spel

- aanvaarding deur ander mense

- 'n vreugdevolle atmosfeer

- prestasies wat vir die kind belangrik is en wat deur sy groep as belangrik en waardevol beskou word.

Om die kleuter emosioneel gelukkig te hou gedurende sy verblyf in die hospitaal, sal die verpleegspan hul moet toelê op bogenoemde faktore soos beskryf deur Hurlock.

\section{Spel in die kleuterjare}

Tussen die rituele en roetines van elke dag bestee die kleuter die meeste van sy tyd aan spel van een of ander aard. Spel is eie aan elke kind, 'n bedrywigheid wat weinig verpligting of dissipline inhou. Tog lewer spel 'n uiters waardevolle bydrae tot die kleuter se liggaamlike, kognitiewe, emosionele, sosiale en persoonlikheidsontwikkeling. Daar is dus weinig, indien enige, aspekte van die kind se ontwikkeling wat nie op die een of ander wyse met spel geassosieër kan word nie (Vander Zanden, $1981: 343$ ).

\section{DOEL VAN DIE ONDERSOEK}

Die doel van hierdie ondersoek kan kortliks soos volg gestel word:

- om kriteria te ontwerp en te evalueer waartydens die verpleegpersoneel begeleidend optree in hul interaksie met siek kleuters

- om ' $n$ indiensopleidingsprogram aan te biéd wat moontlik bogenoemde interaksie tussen die verpleegpersoneel en die kleuter op 'n doeltreffende wyse kan laat plaasvind

- om vas te stel of interaksie tydens begeleiding doeltreffender plaasgevind het tussen die verpleegpersoneel en die kleuter ná die indiensopleidingsprogram.

Die terrein van die empiriese ondersoek sal beperk word tot die verpleegpersoneel wat in 'n hospitaal se pediatriese afdeling werksaam is.

\section{DIE EMPIRIESE ONDERSOEK}

Die empiriese studie behels 'n ondersoek na die doeltreffendheid van interaksie tussen die verpleegpersoneel en die gehospitaliseerde kleuter.

Eksperimentele- en kontrolegroepe is volgens die skaal in tabel 1 geëvalueer. Die interbeoordelaarbetroubaarheid is deur middel van die Friedman-toets bepaal. Albei groepe is onderwerp aan indiensopleiding volgens tabel 2 . Die doeltreffendheid van die indiensopleidingsprogram is volgens die U-toets van Mann Whitney bepaal. 
Tabel 1. Skaal vir evaiuering vir die verpleegpersoneel se interaksie met kleuters in 'n kindersaal

\section{LID VAN DIE VERPLEEGSPAN:}

\section{KERNDIMENSIE}

\section{Identifikasie}

1. Spreek kind nie direk aan tydens kommunikasie nie.

2. Spreek kind aan as hartjie, baba, outjie ens.

3. Spreek kind op noemnaam aan.

\section{Omgewingsorientasie}

1. Kind word in bed/wiegie gesit.

2. Kind word verduidelik dat dit tydelik sy bed/wiegie is.

\section{EVALUEERDER:}

(Kies die toepaslike stelling by elke kerndimensie.)

Punte

3. Kind word gewys dat hy saam met maatjies is en georiënteer tot die fisiese omgewing.

\section{Gehoor}

1. Nie getoets of kind kan hoor nie.

2. Getoets en nie aangeteken nie.

3. Getoets en aangeteken.

\section{KOGNITIEWE- EN TAALONTWIKKELING}

Stimulasie

1. Nie bewus van stimulasie-geleentheid nie.

2. Bewus, maar gebruik dit per geleentheid.

3. Skep geleentheid vir stimulasie en gesels met kind.

\section{Taal}

1. Gesels nie met kleuter nie.

2. Gesels soms met kleuter.

3. Gesels doelbewus met kleuter en luister wat hy sê.

Fisiese versorging

1. Kleuter word afsydig hanteer tydens fisiese versorging.

2. Kleuter word liefdevol hanteer met non-verbale kommunikasie. Stemtoon

3. Kleuter word liefdevol hanteer met verbale kommunikasie tydens fisiese versorging.

1. Intonasie van stem kwaai en aggressief

2. Intonasie van stem emosieloos.

3. Intonasie van stem liefdevol en beheersd.

\section{Gerusstelling}

1. Kwaai stemtoon, poging tot gerusstelling.

2. Toonlose stemtoon gerusstelling.

3. Liefdevolle, vriendelike verbale gerusstelling.

\section{Huilende kleuter}

\section{PERSOONLIKHEIDSONTWIKKELING}

1. Verpleegpersoneellid is geïrriteerd met kind in hantering

2. Verpleegpersoneellid is neutraal met kind in hantering

3. Verpleegpersoneellid is besorgd oor kind in hantering.

\section{Voorligting}

1. Voorligting word nie aan ouers gegee nie

2. Ontoepaslike voorligting word aan ouers gegee.

3. Relevante voorligting word aan ouers gegee.

\section{LIGGAAMLIKE ONTWIKKELING}

Massa

\section{SELFKONSEP}

\section{Vaardigheid}

1. Is nie bewus van kind se motoriese vermoëns nie.

2. Is bewus en reageer nie verbaal nie.

3. Prys kind as hy motories vaardig is.

\section{Grensstelling}

1. Stel geen grense vir die kind nie.

2. Stel grense vir kind sonder verduideliking.

3. Stel grense vir die kind en verduidelik waarom.

1. Glad nie geweeg nie.

2. Geweeg sonder om dit aan te teken.

3. Geweeg met korrekte aantekening.

Roetine

\section{Lengte}

1. Glad nie gemeet nie.

2. Gemeet sonder aantekening.

3. Gemeet met korrekte aantekening.

Tande

1. Glad nie bewus of kleuter tandjies borsel nie.

2. Bewus dat kleuter tandjies borsel en sien toe dat dit gedoen word.

3. Bewus dat kleuter tandjies borsel, ondersteun hom daarin en prys hom verbaal.

1. Beplan geen roetine vir kind tydens daaglikse versorging nie.

2. Beplan roetine sonder verduideliking aan kind.

3. Beplan roetine en verduidelik dit aan die kind.

\section{Motivering}

1. Geen motivering tydens prestasie.

2. Verbale motivering tydens prestasie.

3. Verbale motivering tydens prestasie en volg op deur nog 'n verwagting te stel.

\section{Geslagrolidentiteit}

1. Geen verskil in verwagting van seuns en dogters

2. Bewus van verskil en gee verbaal daaraan aandag deur byvoorbeeld $J y$ is ' $n$ mooi seun.

1. Nie getoets of kind behoorlik kan sien nie

2. Getoets en nie aangeteken nie.

3. Getoets en aangeteken.

3. Gee verbaal aandag sowel as deur spel, byvoorbeeld Seuns speel met motortiies. 


\section{Voeding}

1. Gee kleuter so kos sonder toesig.

2. Gee kleuter se kos in afsondering terwyl hy saam met ander kleuter kan eet, maar met verpleegkundige toesig.

3. Gee kleuter se kos saam met ander kleuters en ondersteun waar Dissipline nodig.

\section{Spesiale ondersoeke}

1. Geen verduideliking of gerusstelling.

2. Verbale verduideliking en gerusstelling.

3. Verbale verduideliking en gerusstelling met demonstrasie en laat die kind sekere instrumente hanteer indien moontlik.

Toiletgewoontes

1. Onbewus van kleuter se toiletgewoontes.

2. Bewus en onsensitief vir toiletgewoontes.

3. Bewus van gewoontes en moedig aan om sukses te behaal

\section{Naboots}

1. Onbewus van kleuter as nabootser.

2. Bewus van kleuter as nabootser maar afsydig en neutraal.

3. Bewus dat kleuter graag naboots en tree altyd as rolmodel op.

\section{EMOSIONELE ONTWIKKELING}

\section{Vrees}

1. Ignoreer vrees by kleuter

2. Respekteer vrees en stel non-verbaal gerus.

3. Respekteer vrees by kleuter en stel verbaal gerus deur positiewe handeling.
SPEL

1. Onbewus van kleuter se omgewing.

2. Bewus van omgewing, maar neutraal.

3. Bewus van omgewing en wys die kind daarop deur verbale kommunikasie.

1. Onbewus van dissipline en aggressief.

2. Bewus van dissipline en onkonsekwent.

3. Pas dissipline konsekwent toe, sodat kind weet wat van hom verwag word en verduidelik handeling.

\section{Kognitief}

1. Onbewus van kleuter se vaardigheid.

2. Bewus van vaardigheid en stimuleer soms.

3. Bewus van vaardigheid en stimuleer doelbewus, asook aanmoediging en prestasiemotivering

\section{Sosiaal}

1. Onbewus van portuur-interaksie tydens spel.

2. Skep soms geleentheid vir portuur-interaksie tydens spel.

3. Bewus van spel met portuurgroep en skep doelbewus geleentheid daarvoor

\section{Selfkonsep}

1. Onbewus van kleuter se selfkonsep tydens spel.

2. Bewus van kleuter se selfkonsep tydens spel en bly neutraal.

3. Bewus van kleuter se selfkonsep tydens spel en sê byvoorbeeld Dit is ' $n$ mooi tekening as kind mooi geteken het.

\section{BEVINDINGS}

\section{Algemene oriëntasie}

Dit wil voorkom of 36,1 persent van die verpleegpersoneel die kleuter nie regstreeks aanspreek gedurende kommunikasie nie, terwyl 56,1 persent die kind op sy noemnaam aanspreek. Ná die proefneming het hierdie persentasies verander tot 7,3 persent en 90,5 persent onderskeidelik.

Slegs 1,5 persent oriënteer die kleuter tot sy fisiese omgewing, waar 92,7 persent hom net in sy bedjie sit en wegloop. Nadat die program aangebied is, het 83,2 persent die kleuter georiënteer tot sy fisiese omgewing en hom ook aan sy mede-pasiëntjies bekendgestel.

Medies-geregtelike-risiko's word deur 75,3 persent van die personeel geïgnoreer terwyl hulle daarvan bewus is, waar 20,7 persent van die personeel sê dat hulle daarvan onbewus was. $\mathrm{Na}$ die programaanbieding was 13,4 persent onbewus daarvan, terwyl 82,3 persent ' $n$ veilige omgewing geskep het.
Die blyk dat 55,0 persent die kleuter liefdevol hanteer gedurende fisiese versorging, maar nie met hom kommunikeer nie. Die personeel wat verbaal kommunikeer, gedurende fisiese versorging van die kind, bestaan uit 13,9 persent. Ná die proefneming het hierdie persentasies verander tot 22,8 persent en 74,3 persent.

Die kleuter word liefdevol en verbaal gerusgestel deur 43,1 persent indien nodig, terwyl dit lyk of 47,7 persent afsydig is in hulle gerusstelling, maar dit wel doen. Dit wou voorkom of die program meegebring het dat 89,6 persent die kind liefdevol en verbaal gerus stel, terwyl dit blyk dat nog 12,0 persent afsydig is.

Verpleegpersoneel wat die huilende kind besorgd hanteer, is 42,6 persent en ná die proefneming 84,2 persent. 54,3 Persent was neutraal in hul hantering van die huilende kleuter, terwyl die persentasie na die proefneming gedaal het tot 12,0 persent.

Dit wou voorkom of 91,3 persent geen voorligting aan ouers gee nie, waar slegs 2,6 persent relevante voorligting verskaf. Nadat die program aangebied is, het 81,6 persent relevante voorligting gegee en 15,1 persent geen voorligting nie.

\section{Liggaamlike ontwikkeling}

Dit lyk of 68,8 persent van die verpleegpersoneel die kleuters se massa met opname bepaal en dit aanteken, terwyl geeneen die lengte bepaal nie. Ná die proefneming het 82,3 persent die massa bepaal en dit aangeteken. Die lengte is toe ook deur 63,3 persent bepaal en aangeteken.

'n Verontrustende meting was dat dit lyk of 96,4 persent van die personeel glad nie daarvan bewus is of die kleuters hul tandjies borsel nie, terwyl slegs 3,5 persent toesien dat dit wel gedoen word en hul verbaal aanmoedig. By die na-proefneming wou dit voorkom of 79,7 persent daarvan bewus was dat die kleuters hul tandjies borsel. Die personeel het die kleuters daarin ondersteun en hulle verbaal ter aanmoediging geloof. 
Tabel 2 INDIENSOPLEIDINGSPROGRAM

\begin{tabular}{|c|c|c|c|}
\hline KERNDIMENSIE & DOEL & INHOUD & HANDELING \\
\hline Identifikasie & $\begin{array}{l}\text { Om die kind in erkentlikheid aan } \\
\text { te spreek. }\end{array}$ & Noemnaam. & Gebruik noemnaam. \\
\hline Omgewingsoriëntasie & $\begin{array}{l}\text { Om die kind veilig te laat voel in } \\
\text { sy onmiddellike omgewing. }\end{array}$ & $\begin{array}{l}\text { Verduidelik aan kind rede vir } \\
\text { hospitalisasie en stel bekend } \\
\text { aan medepasiëntjies }\end{array}$ & $\begin{array}{l}\text { Stel kind gerus en stel bekend aan } \\
\text { fisiese omgewing. }\end{array}$ \\
\hline Medies-geregtelike risiko's & $\begin{array}{l}\text { Die skep van 'n veilige omge- } \\
\text { wing. }\end{array}$ & Identifiseer risiko areas. & Beveilig die omgewing. \\
\hline Fisiese versorging & $\begin{array}{l}\text { Om die kind tydens fisiese ver- } \\
\text { sorging liefdevol te hanteer. }\end{array}$ & $\begin{array}{l}\text { Praat met kind tydens fisiese } \\
\text { versorging. }\end{array}$ & $\begin{array}{l}\text { Liefdevolle hantering en verbale } \\
\text { kommunikasie. }\end{array}$ \\
\hline Gerusstelling & $\begin{array}{l}\text { Om die kleuter liefdevol, verbaal } \\
\text { gerus te stel. }\end{array}$ & $\begin{array}{l}\text { Liefdevolle verbale gerusstel- } \\
\text { ling. }\end{array}$ & $\begin{array}{l}\text { Praat vriendelik en liefdevol met } \\
\text { kind. }\end{array}$ \\
\hline Huilende Kleuter & $\begin{array}{l}\text { Om die huilende kleuter besorgd } \\
\text { te hanteer. }\end{array}$ & Verbale besorgdheid. & Verbale besorgde hantering. \\
\hline Voorligting. & $\begin{array}{l}\text { Om ouers in te lig oor huidige } \\
\text { probleem en hantering van kleu- } \\
\text { ter. }\end{array}$ & Relevante voorligting. & $\begin{array}{l}\text { Verbale verduideliking ten opsigte } \\
\text { van primêre probleem. }\end{array}$ \\
\hline \multicolumn{4}{|c|}{ LIGGAAMLIKE ONTWIKKELING } \\
\hline Massa & $\begin{array}{l}\text { Om te bepaal of kleuter se } \\
\text { massa met sy ouderdom oor- } \\
\text { eenstem. }\end{array}$ & $\begin{array}{l}\text { Die weeg van kleuter met kor- } \\
\text { rekte interpretasie van massa. }\end{array}$ & Weeg kleuter en teken aan. \\
\hline Lengte & $\begin{array}{l}\text { Om te bepaal of kleuter se } \\
\text { lengte met ouderdom ooreen- } \\
\text { stem. }\end{array}$ & $\begin{array}{l}\text { Die meet van kleuter se lengte } \\
\text { met die korrekte interpretasie } \\
\text { volgens ouderdom. }\end{array}$ & Meet kind se lengte en teken aan. \\
\hline Tande & $\begin{array}{l}\text { Om kleuter te ondersteun en } \\
\text { aan te moedig met die borsel } \\
\text { van tande. }\end{array}$ & $\begin{array}{l}\text { Ondersteuning van kleuter } \\
\text { tydens die borsel van tande. }\end{array}$ & $\begin{array}{l}\text { Ondersteun kleuter met die borsel } \\
\text { van tande en prys hom verbaal. }\end{array}$ \\
\hline Visie & $\begin{array}{l}\text { Om vas te stel of kind behoorlik } \\
\text { kan sien. }\end{array}$ & $\begin{array}{l}\text { Fokus van oogkontak waar te } \\
\text { neem. }\end{array}$ & $\begin{array}{l}\text { Laat kleuter prentjie in boeke } \\
\text { identifiseer, toets nou albei ogies } \\
\text { en laat kind prentjie herroep. }\end{array}$ \\
\hline Gehoor & $\begin{array}{l}\text { Om vas te stel of kleuter kan } \\
\text { hoor. }\end{array}$ & $\begin{array}{l}\text { Gebruik 'n ratel en neem kleuter } \\
\text { waar. }\end{array}$ & $\begin{array}{l}\text { Deur ratel te skud en te kyk of } \\
\text { kleuter sy kop draai na die geluid. }\end{array}$ \\
\hline \multicolumn{4}{|c|}{ KOGNITIEWE EN TAALONTWIKKELING } \\
\hline Stimulasie & $\begin{array}{l}\text { Om kleuter te stimuleer met eks- } \\
\text { terne stimuli. }\end{array}$ & $\begin{array}{l}\text { Skep geleentheid vir stimule- } \\
\text { ring. }\end{array}$ & $\begin{array}{l}\text { Gesels en stimuleer, byvoorbeeld } \\
\text { met boeke. }\end{array}$ \\
\hline Taal & $\begin{array}{l}\text { Om taalontwikkeling te stimu- } \\
\text { leer. }\end{array}$ & Identifiseer kommunikasievlak. & $\begin{array}{l}\text { Gesels met kleuter volgens ouder- } \\
\text { dom. }\end{array}$ \\
\hline Stemtoon & $\begin{array}{l}\text { Om altyd liefdevol en beheersd } \\
\text { te praat. }\end{array}$ & $\begin{array}{l}\text { Liefdevolle, beheersde stem- } \\
\text { toon. }\end{array}$ & $\begin{array}{l}\text { Kommunikeer met 'n liefdevolle, } \\
\text { beheersde stemtoon met die kleu- } \\
\text { ter. }\end{array}$ \\
\hline \multicolumn{4}{|c|}{ PERSOONLIKHEIDSONTWIKKELING } \\
\hline \multicolumn{4}{|l|}{ SELFKONSEP } \\
\hline Vaardigheid & $\begin{array}{l}\text { Om vas te stel hoe vaardig kleu- } \\
\text { ter motories is. }\end{array}$ & $\begin{array}{l}\text { Identifiseer motoriese vaardig- } \\
\text { heid. }\end{array}$ & $\begin{array}{l}\text { Prys kleuter indien hy motories } \\
\text { iets regkry, bv. spel of eet. }\end{array}$ \\
\hline Grensstelling & $\begin{array}{l}\text { Om kleuter sekuriteit te gee deur } \\
\text { grensstelling. }\end{array}$ & $\begin{array}{l}\text { Verduideliking van toelaatbare } \\
\text { gedrag. }\end{array}$ & $\begin{array}{l}\text { Verduidelik verbaal aan kleuter } \\
\text { wat toelaatbaar is en wat nie. }\end{array}$ \\
\hline Roetine & $\begin{array}{l}\text { Om kleuter te sosialiseer binne } \\
\text { hospitaalroetine. }\end{array}$ & Verduidelik roetine aan kleuter. & $\begin{array}{l}\text { Hou by roetine sodat kind met ver- } \\
\text { wagtings vertroud raak. }\end{array}$ \\
\hline Motivering & $\begin{array}{l}\text { Om kleuter te motiveer en te } \\
\text { prys vir sy prestasies. }\end{array}$ & Prestasiemotivering. & $\begin{array}{l}\text { Prys kleuter verbaal vir prestasie } \\
\text { en stel nog 'n realistiese verwag- }\end{array}$ \\
\hline
\end{tabular}




\begin{tabular}{|c|c|c|c|}
\hline KERNDIMENSIE & DOEL & INHOUD & HANDELING \\
\hline GESLAGSROLIDENTITEIT & $\begin{array}{l}\text { Om kleuter te laat trots voel op } \\
\text { sy geslag. }\end{array}$ & $\begin{array}{l}\text { Identifikasie van geslag en gee } \\
\text { erkenning. }\end{array}$ & $\begin{array}{l}\text { Verduidelik dat seuns met motor- } \\
\text { tjies en dogters met poppe speel. }\end{array}$ \\
\hline \multirow[t]{2}{*}{ SOSIALISERING } & $\begin{array}{l}\text { Om kleuter saam met mede- } \\
\text { kleuters te laat eet. }\end{array}$ & $\begin{array}{l}\text { Etenstye met mede-kleuters en } \\
\text { ondersteun. }\end{array}$ & $\begin{array}{l}\text { Indien kleuter se toestand dit toe- } \\
\text { laat, laat hy saam met ander eet } \\
\text { en ondersteun waar nodig. }\end{array}$ \\
\hline & $\begin{array}{l}\text { Om kind gerus te stel tydens } \\
\text { spesiale ondersoeke. }\end{array}$ & $\begin{array}{l}\text { Identifiseer vrees by kleuter en } \\
\text { stel gerus. }\end{array}$ & $\begin{array}{l}\text { Verbale gerusstelling en demon- } \\
\text { strasie indien moontlik. }\end{array}$ \\
\hline Spesiale ondersoeke & $\begin{array}{l}\text { Om bewus te wees van kleuter } \\
\text { se toiletgewoontes en of hy nog } \\
\text { doek dra. }\end{array}$ & $\begin{array}{l}\text { Identifiseer toiletgewoontes en } \\
\text { of kleuter doek dra. }\end{array}$ & $\begin{array}{l}\text { Moedig kleuter aan om toiletge- } \\
\text { woontes te beoefen soos tuis aan- } \\
\text { geleer. }\end{array}$ \\
\hline Toiletgewoontes & $\begin{array}{l}\text { Om te alle tye as rolmodel vir die } \\
\text { kleuter op te tree. }\end{array}$ & $\begin{array}{l}\text { Bewus te wees dat kleuters } \\
\text { graag naboots. }\end{array}$ & Altyd 'n rolmodel vir kleuter wees. \\
\hline \multicolumn{4}{|l|}{ Naboots } \\
\hline \multicolumn{4}{|l|}{ EMOSIONELE ONTWIKKELING } \\
\hline Vrees & $\begin{array}{l}\text { Om kleuter gerus te stel en posi- } \\
\text { tief te handel. }\end{array}$ & Identifiseer vrees en stel gerus. & $\begin{array}{l}\text { Stel kleuter verbaal gerus oor } \\
\text { vrees en pas positiewe mega- } \\
\text { nismes toe. }\end{array}$ \\
\hline Omgewingstimulasie & $\begin{array}{l}\text { Om kleuter bewus te maak van } \\
\text { omgewing. }\end{array}$ & $\begin{array}{l}\text { Fisiese omgewing aan kleuter } \\
\text { bekendstel. }\end{array}$ & $\begin{array}{l}\text { Deur verbale kommunikasie die } \\
\text { kleuter te wys op omgewing. }\end{array}$ \\
\hline Dissipline & $\begin{array}{l}\text { Om deur dissipline kind te laat } \\
\text { veilig voel. }\end{array}$ & $\begin{array}{l}\text { Realistiese dissipline en kon- } \\
\text { sekwentheid. }\end{array}$ & Dissipline konsekwent toepas. \\
\hline \multicolumn{4}{|l|}{ SPEL } \\
\hline Kognitief & $\begin{array}{l}\text { Om kleuter aan te moedig en te } \\
\text { prys vir vaardigheid. }\end{array}$ & $\begin{array}{l}\text { Skep geleentheid om vaardig- } \\
\text { heid te stimuleer. }\end{array}$ & $\begin{array}{l}\text { Stimuleer kleuter se vaardigheid } \\
\text { doelbewus, moedig aan en prys. }\end{array}$ \\
\hline Sosiaal & $\begin{array}{l}\text { Om portuurinteraksie deur spel } \\
\text { aan te moedig. }\end{array}$ & Kleuters saam laat speel. & $\begin{array}{l}\text { Skep geleentheid vir kleuter om } \\
\text { met mede-kleuters te speel en } \\
\text { moedig aan. }\end{array}$ \\
\hline Selfkonsep & $\begin{array}{l}\text { Om kleuter se selfkonsep posi- } \\
\text { tief te versterk. }\end{array}$ & $\begin{array}{l}\text { Verbale versterking van kleuter } \\
\text { se selfkonsep. }\end{array}$ & $\begin{array}{l}\text { Prys kleuter vir toepaslike hande- } \\
\text { ling, byvoorbeeld as hy 'n mooi te- } \\
\text { kening gemaak het, sê dit. }\end{array}$ \\
\hline
\end{tabular}

Gedurende die kleuters se hospitalisering blyk dit dat 89,1 persent van die personeel nie toets of die kind behoorlik kan sien nie. Ook gehoor word deur 73,6 persent nie getoets nie. Ná die proefneming het 81,2 persent en 85,2 persent onderskeidelik getoets of die kleuters kan sien en hoor. Dit is ook in die kleuter se lêer aangeteken.

\section{Kognitiewe- en taalontwikkeling}

Personeel wat bewus is van geleenthede om die kleuter te stimuleer en dit per geleentheid benut, is 81,5 persent. Slegs 8,6 persent skep geleentheid om die kind te stimuleer en met hom te gesels. Hierdie persentasie het ná die programaanbieding verander tot 16,5 persent en 80,3 persent onderskeidelik.
Dit blyk dat 79,6 persent soms met die kleuter gesels om taalgebruik te bevorder. Daar is egter 10,7 persent was doelbewus met die kind gesels en luister wat hy sê. Ná die proefneming het 88,3 persent doelbewus met die kind gekommunikeer en geluister, terwyl 11,7 persent soms met hom gesels het.

Stemintonasie word deur 70,1 persent liefdevol en beheersd gebruik, terwyl 27,4 persent emosieloos praat. Ná die program het 76,6 persent liefdevol en beheersde stemintonasie gebruik, terwyl 13,4 persent nog emosieloos in hul kommunikasie voorgekom het.

\section{Persoonlikheidsontwikkeling}

Motoriese vaardighede word deur 44,1 persent van die personeel verbaal geloof, terwyl 24,8 persent onbewus is van die kind se motoriese vaardigheid. Ná die proefneming wou dit voorkom of 7,7 persent van die personeel nog geen aandag gee aan motoriese vaardigheid nie, terwyl 83,4 persent die kleuter verbaal aangeprys het as hy motories vaardig is.

Faktore soos grensstelling en roetine wat die kleuter laat veilig voel in sy omgewing is wel toegepas, maar sonder verduideliking deur 90,5 persent en 88,5 persent onderskeidelik. Hoewel nie al die kleuters dit moontlik begryp het nie, het 75,4 persent ná die proefneming aan hulle verduidelik wat in die hospitaal van hulle verwag word en 74,6 persent het die roetine aan hulle verduidelik.

Verbale motivering by prestasie is deur 59,2 persent van die personeel toegepas en 25,6 persent het die kleuter verbaal lof toegeswaai 
en dit opgevolg deur die stel van nog 'n realistiese verwagting. Ná die program het 69,4 persent die kleuters verbaal gemotiveer en verdere verwagtinge probeer stel, terwyl 24,2 persent hulle verbaal gemotiveer het.

Dit wou voorkom of die program die personeel se aandag op die belang van geslagsrolidentiteit gevestig het, aangesien 99,1 persent verbaal daaraan aandag gegee het. Van hierdie persentasie het 76,5 persent verder gegaan en ook in spel die kind daarvan bewus gemaak, soos byvoorbeeld Seuns speel graag met motortjies. Voor die eksperimentele meting het 24,5 persent geen verskil in hul verwagtinge

\section{Sosialisering}

Aangesien die kleuter self kan eet, blyk dit dat 82,4 persent van die personeel geen regstreekse toesig hou in die etenstye nie. Slegs 11,3 persent laat die kinders wat fisies mobiel is saam eet en ondersteun hulle waar nodig. Ná die eksperimentele meting het 63,6 persent aan gesamentlike etes aandag gegee en die kleuters waar nodig ondersteun.

Gedurende spesiale ondersoeke het 81,5 persent van die verpleegpersoneel slegs die pediater bygestaan met die prosedure. Geen verduideliking of gerusstelling het die ondersoek voorafgegaan nie. Ná die eksperimentele meting, het 40,4 persent van die personeel die kinders vooraf gerusgestel en indien moontlik die ondersoek verduidelik, terwyl 53,1 persent ook die kleuters toegelaat het om die instrumente te hanteer.

Dit wou voorkom of die programaanbieding die belang van toiletgewoontes onder die personeel se aandag gebring het aangesien 91,6 persent die kleuters aangemoedig het om sukses te behaal in hul toiletgewoontes. Voor die program aangebied is was 62,2 persent onbewus van die kleuter se toiletgewoontes.

Dit lyk of die verpleegpersoneellid die feit dat sy 'n rolmodel is, ernstig benader het, aangesien 95,1 persent daarvan bewus was dat die kleuter graag naboots en dat sy daarvolgens moet optree. Voor die proefneming was 71,5 persent ook daarvan bewus.

\section{Emosionele ontwikkeling}

Vrees by die kleuter is moontlik deur onkunde geïgnoreer deur 40,3 persent van die personeel. 37,1 Persent het die kind non-verbaal gerusgestel in tydperke waarin die kind vrees ondervind, terwyl 22,6 persent die kleuter verbaal gerusgestel het en dit opgevolg het met 'n positiewe handeling deur byvoorbeeld die oorsprong uit te skakel of die kind daarmee bekend te stel.

Bogenoemde waarnemings het ná die proefneming gewysig tot 4,0 persent, 26,4 persent en 69,6 persent onderskeidelik.

Dit blyk dat 86,1 persent van die personeel onbewus was van omgewingstimulasie by die kleuter. Slegs 0,8 persent het die kleuter telkens verbaal op sy omgewing gewys, terwyl 76,3 persent dit ná die programaanbieding toegepas het.

84,3 Persent van die verpleegpersoneel het dissipline inkonsekwent toegepas voor die program, terwyl 78,8 persent dit ná die program konsekwent toegepas het en 15,2 persent nog inkonsekwent was in hul dissiplinering van die kleuter.

\section{Spel}

Om die kleuter se kognitiewe vaardighede te stimuleer is noodsaaklik, hoewel dit tydrowend kan wees in die hospitaal-situasie. Gemiddeld 85,5 persent van die personeel is onbewus van die kleuter se kognitiewe vaardighede. Slegs 14,5 persent was bewus daarvan en het dit soms gestimuleer.

Ná die proefneming het 70,1 persent probeer om die kleuter se spelbehoeftes te bepaal en om die kind met die regte speelgoed volgens sy ouderdom en vaardigheid te stimuleer.

Dit wou voorkom of nie een van die personeel doelbewus vir die kind geleentheid geskep het om met ander kleuters te speel nie. 93,4 Persent van die personeel was onbewus van die feit dat geleentheid geskep moet word vir spel met 'n portuurgroep. Dit blyk dat die programaanbieding 66,4 persent van die personeel gemotiveer het om geleenthede vir portuurgroepinteraksie gedurende kleuterspel te beplan.
Hoewel 39,2 persent van die personeel die kleuters in spel aangemoedig het om hulle selfbeeld te versterk, het 85,0 persent dit toegepas ná die proefneming.

\section{AANBEVELINGS}

$\mathrm{Na}$ aanleiding van die voorafgaande bevindings wil die ondersoeker sekere aanbevelings maak wat moontlik kan help om die interaksie tussen die verpleegpersoneel en die gehospitaliseerde kind te verhoog.

Dit wou voorkom of die oriëntasie wat aan die verpleegpersoneel gegee is, moontlik onvoldoende kan wees. Die volgende aanbevelings word dus gemaak.

\section{Beplanning}

'n Oriëntasieprogram moet deeglik beplan en by die afdeling se interne beleid ingeskakel word.

\section{Oriëntasie}

Alle kategorieë verpleegpersoneel moet georiënteer word voordat hulle die kinders versorg.

\section{Deurlopende evaluasie}

Deurlopende evaluering van die personeel moet gedoen word om vas te stel of hulle die oriëntasie en interne beleid van die afdeling verstaan.

\section{Indiensopleidingsprogram}

'n Behoeftebepaling moet gedoen word oor watter indiensopleidingsprogramme aangebied kan word, soos byvoorbeeld oor medies-geregtelike-risiko's en in kommuniksievaardighede.

\section{Rekordhouding}

Kontrolemaatreëls moet aanwesig wees wat verseker dat rekordhouding volledig is, om sodoende 'n vollediger kindbeeld van die pasiëntjie te kry.

\section{Leergeleenthede}

Ten opsigte van beskikbare leergeleenthede in die afdeling, word die volgende aanbevelings gemaak:

- dat die afdeling voorsien moet word van plakkate oor sekere onderwerpe. Hierdie plakkate 
kan dan in die demonstrasiekamer of verbandkamer van 'n afdeling aangebring word, waar al die verpleegpersoneel toegang daartoe het

- boeke moet beskikbaar wees vir personeel wat sekere onderwerpe oor die kind wil naslaan. Nie alleen oor die kind se siektebeeld nie, maar ook oor aspekte soos watter speelgoed 'n mens aan 'n driejarige kleuter gee om hom handvaardig te maak

- die personeel moet onderrig word in aspekte soos om die kind psigies vir spesiale ondersoeke voor te berei, vrees by die kind te hanteer en die kind te motiveer.

\section{Evalueringsinstrument}

Elke pediatriese afdeling behoort sy eie evalueringsinstrument op te stel volgens sy eie behoeftes. Daar is egter gemeenskaplike behoeftes by alle kinders. Die volgende aanbevelings word gemaak:

- dat die verpleegkundige in bevel van die afdeling 'n komitee byeenroep om hierdie instrument op te stel

- dat die evalueringskaal in tabel 1 as riglyn gebruik kan word

- die personeel vooraf ingelig moet word waarop hulle geevalueer word.

\section{BEPERKINGS VAN HIERDIE NAVORSING}

Daar is sekere beperkings in die navorsing wat uitgelig moet word soos:

- die verpleegpersoneel het waarskynlik nie met die indiensopleidingsprogramme 'n langtermyn verandering ondergaan nie

- die indiensopleiding in opvoedingskonteks sal nutteloos wees as die personeel nie deurlopend die teoretiese onderbou ontvang nie

- begeleiding in die kliniese praktyk area moet deurlopend die opvoedingskonteks insluit, so nie sal hierdie faset van verpleegsorg agterweë bly en die indiensopleiding nie help nie.

\section{EMPIRIESE BEDUIDENHEID VAN DIE NAVORSING}

Die interbeoordelaarskoëffisiënt van 24,9 is verkry by die beoordeling van interaksies met die kleuters, volgens die Friedmantoets.

Op die $5 \%$ betekenispeil : $\mathrm{X}^{2} \geqslant$ 19,68 en

op die $1 \%$ betekenispeil : $\mathrm{X}^{2} \geqslant$ 24,72 .

Dit wil dus voorkom of die interbeoordelaarbetroubaarheid $99.9 \%$ aanvaar kan word.

Die effek van die indiensopleidingsprogram se beduidenheid op die verpleegpersoneel is bepaal deur middel van die U-Toets van Mann Whitney, waar $Z=5,12$.

Op die $5 \%$ betekenispeil : $X^{2} \geqslant 1,6$ Op die $1 \%$ betekenispeil : $\mathbf{X}^{2} \geqslant 2,3$.

Dit blyk dat die indiensopleidingsprogram 99,9\% geslaagd was.

\section{SLOT}

Waar die ouers van elke kind wat gehospitaliseer moet word noodgedwonge sy kind aan die hospitaal en sy personeel moet afstaan, is dit die verpleegspan se verantwoordelikheid om toe te sien dat hierdie kind se nood aan opvoeding nie geïgnoreer word nie. Ons kan egter alleenlik effektief op hierdie nood reageer as ons toegerus is met die nodige kennis en vaardigheid en as die toepassing daarvan deel van ons menswees geword het.

\section{BIBLIOGRAFIE}

Allpor, G.W. (1979) Patrem and growth in personality. New York. Holt, Rinehart \& Winston.

Atkinson, J.W. (1968) An introduction to motivation. Prin ceton, Van Nostrand Company.

Bee, H.L. (1981) The developing child New York. Harper \& Row.

Bhana, K. (1983) The development of gender understanding in children. Pietermaritzburg. Rand McNally.

Bigner, J.J. (1983) Human development. New York. Macmillan.

Bigot, L.C.T. (1968) Het kind. Groningen. J.B. Wolters.

Bledsoe, J.C. (1964) Selfconcepts of children and their intelligence, achievement, interests and anxiety. Journal of Individual Psychology. Vol. 20, 55-58.

Bower, T.G.R. (1979) Human Development. San Francisco. Freeman

Buss, A. A.; Plomin, R.A. (1975)A temperamental theory of personality development. New York. Wiley.

Craig, G.J. (1983) Human Development. Englewood Cliffs. Prentice-Hall.

Elliot, J.R. (1975) Living in hospital. Londen. King Ed ward's Hospital Publication.

Engelbrecht, C.S.; Kok, J.C.; Van Biljon, S.S. (1982) Vol wassewording. Johannesburg. Butterworth.

Erikson, E.H. (1968) Identity, youth and crisis. London. Faber \& Faber.

Erikson, E.H. (1975) Childhood and society. Penguin Books. Hogarth Press.

Fein, G.G. (1978) Child development. Englewood Cliffs Prentice-Hall.

Garbers, J.G. (1981) Aspekse van die opvoeding van die vier-tot agtjarige kind. Port Elizabeth. Publikasiereeks van die Universiteit van Port Elizabeth.

Ginsberg, H.; Opper. S. (1979) Piaget's theory of intellectual development. Engle wood Cliffs. Prentice-Hall

Hall, E.; Lamb. M.E.; Perlmuther, M. (1982) Child psychology today. New York. Random House.

Hurlock, E. B. (1980) Child development. New York. McGraw-Hill. 6th Ed.

Kohlberg, L.A. (1966) A cognitive-developmental analysi of children's sex-role concepts and attitudes. Stanford. University Press.

Kolesnik, W.B. (1978) Morivation, understanding and influencing human behaviour. Boston. Allyn \& Bacon.

Lerner, R.M.; Hultsch, D. (1983) Human Development. New York. McGraw-Hill.

Muller, E.C.C. (1979) Evaluering van 'n begeleidingsinstrument vir onderwysersopleiding. Potchefstroom. P.U vir C.H.O. (D.Ed.-proefskrif).

Piaget, J.; Inhelder, B. (1969) The psychology of the child. London. Routledge \& Kegan Paul

Piek, J. (1981) Die kind en die hospitaal. Pretoria. H.A.U.M

Rethlingshafer, D. (1963) Motivation as related to personality New York. McGraw-Hill.

Sarafina, E.P.; Armstrong, J.W. (1980) Child and adolescent development. Glenview. Scott \& Foresman.

Schell, R.E.; Hall, E. (1979) Developmental psychology roday. Random. Hogharth Press.

Sears, L.R. (1970) Relation of early socialization experiences on self-concepts and gender role in early childhood. New York. Wiley

Smith, C.F. (1983) Motivation: non-cognitive aspects of children's performances. London. The Claredon Press.

Thomas, A.; Chess, S. (1977) Temperament and development. New York. Bruwer.

Vander Zanden, J.D. (1981) Human Development. New York, Knopf.

Van Rensburg, K. (1981) Die kind en sy inskakeling by die hospiraal. Pretoria. H.A.U.M

Wright. E. (1972) The new childhood. London. Tandem.

Yura, H.; Walsh, M.B. (1973) The nursing process. New York. Appleton-Century-Crofts. 